\title{
Aeroallergen Sensitivity of Atopic Children in Alanya Region
}

\author{
Alanya Bölgesinde Atopik Çocuklarda Aeroalerjen \\ Duyarlılığı
}

Esra Hazar Sayar ${ }^{1}$,

${ }^{1}$ Pediatric Allergy Immunology Unit, Training and Research Hospital in Alanya, Antalya, Turkey

Geliş Tarihi/Received: 19 August 2019 Kabul Tarihi/Accepted: 26 December 2019

Address correspondence to: Esra Hazar Sayar, Pediatric Allergy Immunology Unit, Training and Research Hospital in Alanya, Antalya, Turkey

e-mail: ehsayar@gmail.com

\section{ORCID}

Esra Hazar Sayar

https://orcid.org/0000-0003-0338-1040

\begin{abstract}
Öz
Amaç: Alerjik hastalıklarda semptomları azaltmak ve yaşam kalitesini arttırmak için sorumlu alerjenleri belirlemek önemlidir. Bu nedenle bölgemizdeki alerjik hastalarda aeroalerjenlerin duyarlılığını ve sıklığını değerlendirmeyi amaçladık.

Hastalar ve Yöntem: Çalışmaya, Eylül 2017-Mart 2018 tarihleri arasında pediatrik alerji immünoloji polikliniğine başvuran 1078 hasta (2-18 yaş) dahil edildi. Deri prick testinde en az bir alerjik duyarlılık saptanan 642 hastanın klinik ve demografik özellikleri, total lgE düzeyleri, kandaki periferik eozinofil sayıları, aeroalerjen duyarlılıkları hasta dosyalarından retrospektif olarak değerlendirildi. Çalışma için Alanya Alaaddin Keykubat Üniversitesi Tıp Fakültesi Yerel Etik Kurulundan onay alındı.

Bulgular: Hastaların 642'sinde $(\% 59.5)$ en az bir aeroalerjene karşı pozitif yanıt gözlendi. Hastaların $\% 34.8$ 'inde astım, \%73.7'sinde alerjik rinit, \%12.6'sında atopik dermatit ve \%3'ünde kronik ürtiker tanısı vardı. $159(\% 24.8)$ hastada birden fazla alerjik hastalık tanısı vardı. Pozitif cilt prick testi olan hastaların

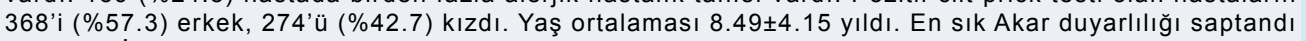
(\%76.1). İkinci sıklıkta küf mantarları (51.8\% Alternaria alternata, $41.7 \%$ Claudosporum herbarum) ve üçüncü sıklıkta grass ve cereal polen (39.8\%) duyarlılığı gözlendi. Diğer aeroalerjen duyarlılık sıklıkları; yabani ot polen karışımı (\%24.6), ağaç polen karışımı (\%21.7), hamamböceği (\%17.8), kedi tüyü (\%31.2), zeytin ağacı (\%20) olarak saptandı. Ortalama serum total IgE düzeyi $215.6 \mathrm{IU} / \mathrm{ml}$ ve ortalama eozinofil sayısı $410.63 / \mathrm{mm}^{3}$ idi.

Sonuç: Alerjik hastalıklarda sorumlu alerjenlerin tespit edilmesi semptomların kontrol edilmesi ve seçilmiş vakalarda immünoterapi şansı vererek hastalık seyrini değiştirebilmesi açısından önemlidir.
\end{abstract}

Anahtar Kelimeler: Alerjen, Atopi, Çocuk, Deri prik test

\begin{abstract}
Aim: It is important to identify allergens in reducing disease-related symptoms and improving quality of life in the allergic diseases. Therefore, we aimed to evaluate the frequency of aeroallergens in allergic patients in our region.

Patients and Methods: 1078 patients (2-18 years) who applied to the pediatric allergy immunology outpatient clinic between September 2017- March 2018 were included to the study. The demographic and clinical characteristics of 642 patients with at least one allergic sensitization in the skin prick test were evaluated retrospectively. Total IgE levels, peripheral eosinophil counts in the blood, aeroallergen sensitivities in skin prick test were evaulated from the patient's files. The study was approved by the Ethics Committee of the Alanya Alaaddin Keykubat Medical Faculty.

Results: In 642 of the patients $(59.5 \%)$, a positive response was observed against at least one aeroallergen. Among patients, $34.8 \%$ had asthma, $73.7 \%$ had allergic rhinitis, $12.6 \%$ had atopic dermatitis, and $3 \%$ had chronic urticaria. $24.8 \%$ of the patients $(159)$ had more than one allergic disease. When the evaulation of the patients with positive skin prick test, $57.3 \%$ were male and $42.7 \%$ were female. The mean age was $8.49+/-4.15$ years. The sensitivity of house dust mites was the most common $(76.1 \%)$. In the second and third frequency, molds (51.8\% Alternaria alternata, $41.7 \%$ Claudosporum herbarum) and grass and cereal pollen $(39.8 \%)$ sensitivity were observed. Other determined aeroallergen sensitivity frequencies were; weed pollen mixture $(24.6 \%)$, trees pollen mixture $(21.7 \%)$, cockroach $(17.8 \%)$, cat hair $(31.2 \%)$, olive tree (20\%). The mean serum total IgE level was $215.6 \mathrm{IU} / \mathrm{ml}$ and the mean eosinophil count was $410.63 / \mathrm{mm}^{3}$. Conclusion: Detection of responsible allergens is important to control symptoms and to give the chance the course of the disease with immunotherapy in the selected cases.
\end{abstract}

Key words: Allergen, Atopy, Children, Skin prick test

Cite this article as: Sayar EH. Aeroallergen Sensitivity of Atopic Children in Alanya Region. Selcuk Med J 2020;36(3): 226-231

Disclosure: Author has not a financial interest in any of the products, devices, or drugs mentioned in this article. The research was not sponsored by an outside organization. Author has agreed to allow full access to the primary data and to allow the journal to review the data if requested. 


\section{INTRODUCTION}

Allergy is a hypersensitivity reaction that occurs mostly by lgE and cell mediated mechanisms initiated by specific immunologic triggers. The prevelance of allergic rhinitis, asthma, atopic dermatitis, conjunctivitis and food allergy has increased in recent years (1).

Atopy is an important risk factor for the occurrence of allergic diseases. Atopy is a familial predisposition characterized by sensitization after exposure to allergens in childhood and adolescence and production of $\mathrm{IgE}$. As a result, they may develop symptoms of rhinoconjunctivitis, eczema or asthma. Atopy is used for individuals sensitized to allergens, which are normally found in the environment, where everyone is exposed but the majority does not produce long-term IgE antibodies (2). The diagnosis of IgE-mediated allergies suspected by history and examination in childhood should be basis of validated tests such as skin prick tests, serum-specific IgE tests. Allergy tests are important in terms of avoidance of specific allergen, disease monitorization, treatment planning and specific immunotherapy. Accurate determination of the allergen (inhaler, food or drug) that produces the symptoms is important for making allergen focused logical avoidance plan and avoiding unnecessary elimination in negative tests (3). The appropriate avoidance from the responsible allergen may reduce the allergic load, for example, to improve lung function in asthmatic patients, normalize inflammation markers and decrease the necessity for medication (4).

GA2LEN skin test study III that is a large multicenter study, among the 3034 patients, $68.2 \%$ of them were found to be sensitized to at least one allergen. Eight allergens provide to determinate more than $95 \%$ of sensitized patients (grass pollen, house dust mites, birch pollen, cat epitel, Artemisia, olive pollen, cockroach and Alternaria) (5). In a study to invest geographical variation to environmental aeroallergens in the European Community Respiratory Health Survey I; there was substantial geographical variation in the prevalence of the nine allergens tested. Most common allergen sensitivities were against house dust mites, grass pollen and cat. Other allergens were less common (Cladosporium, Parietaria and common ragweed). There were significant differences in the prevalence of sensitizations between countries and also between centers within countries. Thus allergens vary according to geographical region, knowledge of sensitizations in the area is important for the environmental measures should be taken (6). Regional epidemiological data for the allergens may help to management and avoiding of allergic diseases for that area. The aim of the study is to investigate the allergen sensitization of common respiratory allergens in atopic children in our province.

\section{PATIENTS AND METHODS}

Between September 2017 and March 2018, 1078 patients (2-18 years) who were admitted to the Pediatric Allergy Immunology outpatient clinic with a history of allergic disease and applied skin prick test were enrolled in the study. The demographic characteristics, diagnosis, total IgE levels, peripheral eosinophil counts, aeroallergen sensitivities of 642 patients who had sensitivity to at least one aeroallergen were evaluated retrospectively from the patient's files. The study was approved by the Local Ethical Committee of the Alanya Alaaddin Keykubat University Medical Faculty.

Skin prick tests were performed by the same nurse as previously described (3). As a positive control, histamine solution $(1.7 \mathrm{mg} / \mathrm{ml}$ histamine hydrochloride), saline solution for negative control, standard allergen solutions for aero allergens (Allergopharma $\mathrm{GmbH}$ \& Co. Hamburg/Germany) were used. Briefly, allergen solutions were dripped on the forearm. They were pricked with the lancet (Mizollen; H. Herenz $\mathrm{GmbH}$, Hamburg/Germany) and evaluated 15 minutes later. Three $\mathrm{mm}$ or more enduration response according to negative control was considered as positive reaction. In skin prick test; House dust mites (D. farinea, D. pteronyssinus), grass and cereal pollens (Kentucky blue grass, Timothy grass, Meadow fescue, Rye grass, Velvet grass, Orchard grass, Barley, Oats, Wheat, Rye), weeds (Mugwort, Dandelion, Nettle, English plantain, Wall pellitory), early and mid-term blooming tree pollens (Alder, Elm, Hazel, Poplar, Willow, Birch, Beech, Oak, Plane tree), olive tree pollen, molds (Alternaria alternata, Cladosporium herbarum), cat hair, cockroach (Blatella germanica) sensitivities were evaluated. House dust mite sensitivity was defined as a positive reaction to at least one of Dermatofagoides allergens. Tree pollen sensitivity was defined as a positive reaction to at least one of the early or middle flowering trees. Fungal sensitivity was defined as a positive response to at least one of Alternaria alternata or Cladosporium herbarum.

\section{RESULTS}

In 642 of the patients (59.5\%), a positive response 


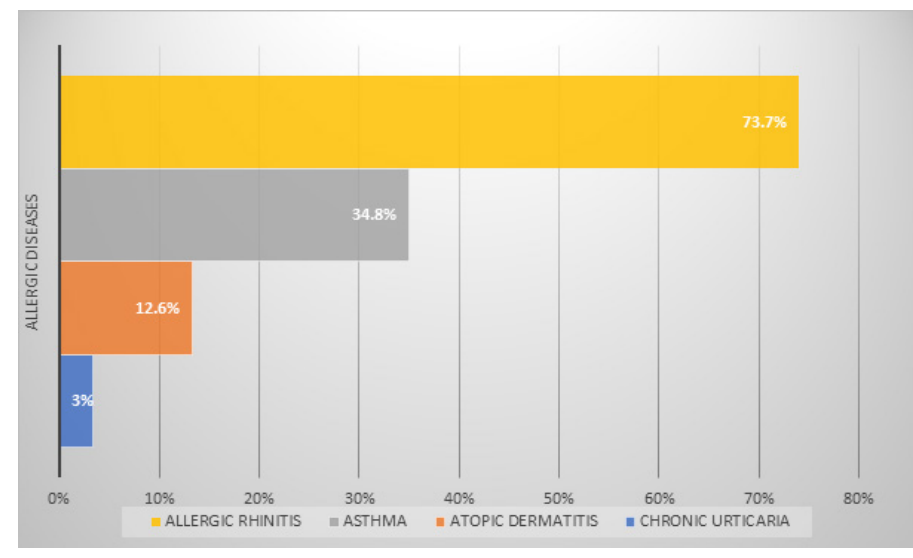

Figure 1. Diagnosis of the patients

was observed against at least one aeroallergen. In $480(74.8 \%)$ cases, sensitivity to more than one aeroallergen was detected. When we look at the diagnoses of the cases, $34.8 \%$ had asthma, $73.7 \%$ had allergic rhinitis, $12.6 \%$ had atopic dermatitis, and $3 \%$ had chronic urticaria (Figure 1). Diagnostic distribution; $50.5 \%$ allergic rhinitis, $14.9 \%$ asthma, $7.5 \%$ atopic dermatitis, $3 \%$ chronic urticaria, $19 \%$ asthma + allergic rhinitis, $0.9 \%$ asthma + atopic dermatitis, $4.2 \%$ allergic rhinitis + atopic dermatitis. $57.3 \%$ of the patients with positive skin prick test were male and $42.7 \%$ were female. The mean age of the patients was $8.49+/-4.15$ years. The sensitivity of house dust mites was the most common sensitivity $(76.1 \%)$. The second frequency of molds $(51.8 \%$ Alternaria alternata, $41.7 \%$ Cladosporium herbarum),

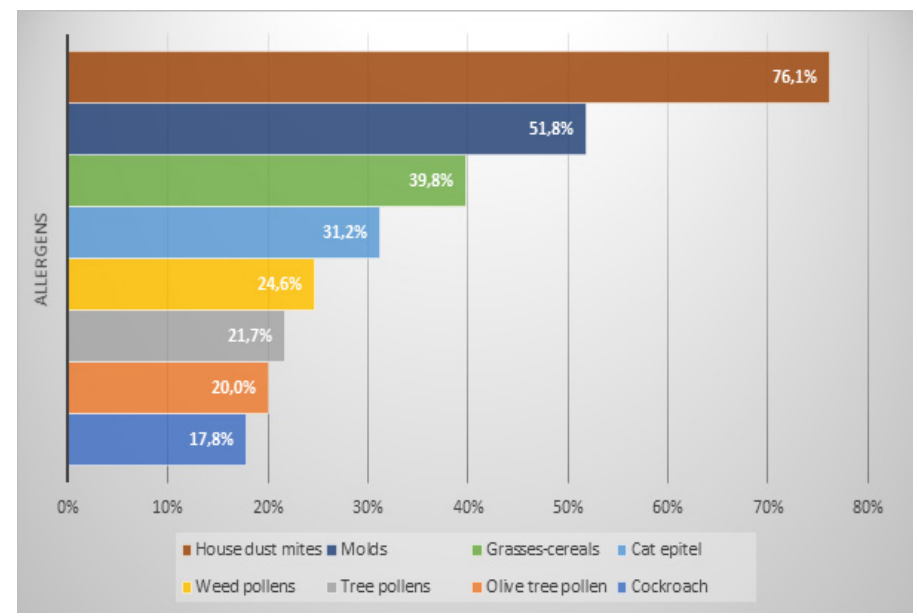

Figure 2. Distribution of aeorallergens the third frequency of grass and cereal pollen $(39.8 \%)$ sensitivity was observed. Other aeroallergen sensitivity frequencies; weed pollen mixture $(24.6 \%)$, trees pollen mixture $(21.7 \%)$, cockroach $(17.8 \%)$, cat hair $(31.2 \%)$, olive tree (20\%) (Figure 2$)$.

Serum total IgE level mean was found to be 215.6 $\mathrm{IU} / \mathrm{ml}$ (median= $138 \mathrm{IU} / \mathrm{ml}$ ) in 489 patients. Mean eosinophil counts in 542 patients was found to be $410.63 / \mathrm{mm}^{3}$ and median was $300 / \mathrm{mm}^{3}$. There was no significant difference in eosinophil and total lgE levels between the patient groups with allergic rhinitis, atopic dermatitis and chronic urticaria ( $p>0.05)$. The mean eosinophils of patients who have asthma were higher than the patients without asthma and the difference was statistically significant $(p<0.05)$. When we look at allergen sensitivities according to allergic diseases; house dust mites were the most common in all patient groups; molds were second, grasses and cereal pollens were third most common allergens. When the patients have allergic rhinitis compared to without allergic rihinitis, there was significant difference in terms of house dust mites and Alternaria $(p<0.05)$. In patients with allergic rhinitis, the sensitivity of house dust mites and Alternaria alternata was found to be higher $(p=0.02, p=0.03$, respectively). There were no differences between the two groups in terms of other allergens. There were no significant differences in asthma, atopic dermatitis and chronic urticaria between the groups with and without disease in terms of allergen sensitivity.

\section{DISCUSSION}

The incidence of allergic diseases increased in the last decades (1). Asthma from allergic diseases is the most common chronic disease in childhood. Increased prevalence is also important in terms of morbidity, emergency applications, economic burden and missed school/work days due to hospital admission. Uncontrolled asthma is also important because of limiting physical activity and growth retardation (7). Allergic rhinitis, which is an allergic disease that usually starts in childhood, causes sleep disturbance, fatigue, headache, concentration difficulty, recurrent runny nose, itching and redness of the eyes and nose. It causes to decrease of quality of life with all these conditions (8). Patients with atopic dermatitis, another prevalent allergic disease in childhood, are irritable due to itching, and their skin is generally dry. Allergic rhinitis and asthma are often coexist $(7,9)$. Some quality of life studies have found that atopic dermatitis has a greater 
effect on the family than diabetes (10). Because of all these medical, economic and social effects, early recognition of allergic diseases and the effective treatment of responsible allergens are becoming increasingly important. Knowing the allergens that are commonly seen geographically is also important in terms of taking general environmental measures. $73.7 \%$ of the patients who were examined for atopy had allergic rhinitis, $34.8 \%$ had asthma, $12.6 \%$ had atopic dermatitis and $3 \%$ had chronic urticaria clinic. Diagnostic distribution was $50.5 \%$ allergic rhinitis, $14.9 \%$ asthma, $7.5 \%$ atopic dermatitis, $3 \%$ chronic urticaria, $19 \%$ asthma + allergic rhinitis, $0.9 \%$ asthma + atopic dermatitis, $4.2 \%$ allergic rhinitis + atopic dermatitis. In a study examining the aeroallergens sensitivity of atopic children in the Mediterranean region published in 2018, $57.8 \%$ of patients had asthma, $28 \%$ had allergic rhinitis, $10.9 \%$ had asthma + allergic rhinitis and $2.9 \%$ had atopic dermatitis (11). The reason for the high number of patients with asthma was the fact that the study was performed together with pediatric chest diseases.

In our study, the sensitivity of house dust mites was the most common (76.1\%). The second frequency of molds $(51.8 \%$ Alternaria alternata, $41.7 \%$ Cladosporium herbarum), the third frequency of grass and cereal pollens (39.8\%) sensitivity was observed. Other aeroallergen sensitivity frequencies; weed pollen mixture $(24.6 \%)$, trees pollen mixture $(21.7 \%)$, cockroach $(17.8 \%)$, cat hair $(31.2 \%)$, olive tree $(20 \%)$ was determined. Basaran et al (11) similarly, in the study carried out in atopic children in the Mediterranean Region, house dust mite sensitivity (69\%) was observed most frequently, but second and third tree pollen (54.9\%) and grass and cereal pollens $(52.5 \%)$ were found to be sensitive. In the same study, animal epithelium mixture was found to be $45.3 \%$, mold mixture $43.4 \%$, weed pollen mixture $34.9 \%$, cockroach $16.9 \%$, olive tree pollen $6 \%$. In that study, there was any difference in the allergen sensitivity according to the season. In our study, mite, molds, weeds, cockroach sensitivity rates were similar to Mediterranean Region, and olive tree pollen sensitivity was found to be higher. In a study conducted in 1037 atopic children in Mersin, the sensitivity of house dust mite 1 was $67.9 \%$, mite 2 was $67.2 \%$, Alternaria alternata was $19.4 \%$, and grass pollen was $17.7 \%$. Diagnosis distributions of patients were; $38.9 \%$ allergic rhinitis, $32.9 \%$ asthma, $15.9 \%$ urticaria and $5.9 \%$ atopic dermatitis (12). Although mite sensitivity is similar in the neighboring province of our center in the Mediterranean region, molds sensitivity was found to be higher in our study.

In a study conducted in Sakarya province in the Western Black Sea Region, a positive reaction was observed in $46 \%$ skin prick test of 623 patients (1-12 yearsold) with allergic rhinitis. In this study, $87 \%$ to pollens (weed: $66 \%$ and trees: $21 \%$ ); $51 \%$ to mites; $8 \%$ to molds; $6 \%$ to animals and $6 \%$ sensitivity to nutrients were detected (13). In a study of 2-17 yearold children in the Central Black Sea Region, the most positive response was against house dust mites $(97 \%)$, and second frequency against diverse plant pollen (grass and trees) (30.6\%). Other sensitivites were molds (12\%) and cockroach (12.3\%) (14). In a study in the Eastern Black Sea Region, 421 patients aged between 3-17 years with at least one aeroallergen sensitivity were evaluated. In the evaluation of these 421 patients, it was found $71 \%$ grass pollen sensitivity, $61 \%$ house dust mites sensitivity, $12.8 \%$ molds sensitivity (Alternaria and Cladosporium) (15). The most common allergens in the test results of 583 patients between the ages of 3-70 years (mean 30.6 \pm 17.5 ) who had been diagnosed with allergic asthma, atopic dermatitis, chronic urticaria, allergic rhinitis, conjunctivitis, sinusitis, pharyngitis in Çanakkale province were house dust mites $(50.5 \%)$, grasses $(28.8 \%)$, cereal pollen $(29 \%)$, cat hair $(14.7 \%)$, dog hair $(16.3 \%)$, pollens $(9.5 \%)$, molds $(9.1 \%)$ and olive tree $(8.8 \%)$ (16). In Istanbul, Küçükosmanoğlu et al (17) applied skin tests to 532 atopic children; positivity was found in 92 patients $(17.2 \%)$, the most common sensitivity was found to the house dust mites (96.7\%). Secondly, the sensitivity of grass pollen $(18.5 \%)$ was determined.

In a study conducted in Ankara, at least one aeroallergen sensitivity was detected in 862 (35.1\%) of 2547 children (2-18 years) who underwent skin prick test with respiratory problems. In that study, the most common allergen was grass pollen $(70.3 \%)$, the second common allergen was house dust mites $(29 \%)$. The other sensitivities were found to weed pollens $(23.1 \%)$, cat epitel $(13.3 \%)$, molds (Alternaria $7.2 \%$, Cladosporium 2.2\%), olive tree pollens $(3.1 \%)$, cockrach $(4.6 \%)(18)$. Atopy is seen to be more common in male sex (19). In our study, $57.3 \%$ of the patients with skin prick test positivity were male and $42.7 \%$ were female according to the literature. Eosinophils affect the pathogenesis and pathophysiology of asthma. Many studies have reported that high blood eosinophils are associated with bronchial hyperreactivity, respiratory inflammation 
in children with recurrent wheezing, uncontrolled asthma, increase in future asthma attacks and use of excessive short acting 32 -agonist (20-23). High blood eosinophil levels are risk factors for both asthma exacerbation and asthma development. In a longitudinal study from 2007 to 2015 including patients older than 20 years who did not initially have asthma $(n=57975)$; high blood eosinophils at baseline was significantly associated with increase in the asthma incidence (24). In our study, there was no noticeable difference in eosinophil and total IgE levels between the patients with allergic rhinitis, atopic dermatitis and chronic urticaria $(p>0.05)$. The mean eosinophils of patients with asthma were higher than those without asthma $(p<0.05)$.

In our region, the winter is warm and humid the summer is very hot and dry. Mediterranean climate is seen and our region is in the humid category according to Erinç precipitation efficiency index (25). The highest rates of mite fauna study in seven regions of Turkey were found in the Mediterranean (48.4\%) and Black Sea (46\%) regions. The presence of mites was related to an increase both in mean temperature ( $>15$ degrees $C$ ) and in humidity ( $>$ or $=40 \%$ ) as well as low altitude $(<300 \mathrm{~m})$. This study suggests that the mite population of humid coastal regions of Turkey is prevalent (26). House dust mite sensitization is a significant risk factor for asthma and rhinitis, particularly in the Tropics where they grow all year (27). Our region has tropical climate characteristics due to rainy winters and very hot summers. In our study, high house dust mite sensitivity is associated with warm and humid climate of our region and low altitude. A previous study from Adana, which is a city with hot and humid climate in the southern region of Turkey, found that the most common respiratory allergens were house dust mites $(73.8 \%$ and $71.6 \%)$ and molds (23.4\%) (28). In another study from Mersin, which is also nearby Mediterranean Sea and has hot and humid climate, the most common aeroallergens were house dust mites and Alternaria alternata (12).

In our study, we detected common inhaler allergen sensitivities for the first time in our region. Prevention from allergens is important to control the disease in atopic diseases. We believe that our study will contribute to disease control by taking protective measures against allergens responsible for atopy.

Conflict of interest: Author declares that there is no conflict of interest between the authors of the article.

Financial conflict of interest: Author declares that he did not receive any financial support in this study.

Address correspondence to: Esra Hazar Sayar, Pediatric Allergy Immunology Unit, Training and Research Hospital in Alanya, Antalya, Turkey

Tel: 00905339490874

e-mail: ehsayar@gmail.com

\section{REFERENCES}

1. Asher MI, Montefort S, Björkstén B, et al. Worldwide time trends in the prevalence of symptoms of asthma, allergic rhinoconjunctivitis and eczema in childhood: ISAAC Phases One and Three repeat multicountry cross-sectional surveys. Lancet 2006:368:733-43.

2. Johansson SG, Bieber T, DahI R, et al. Revised nomenclature for allergy for global use: Report of the nomenclature Review Committee of the World Allergy Organization, October 2003. J Allergy Clin Immunol 2004;113(5):832-6.

3. Eigenmann PA, Atanaskovic-Markovic M, Hourihane JO'B, et al. Testing children for allergies: Why, how, who and when An updated statement of the European Academy of Allergy and Clinical Immunology (EAACI) Section on Pediatrics and the EAACI-Clemens von Pirquet Foundation. Pediatr Allergy Immunol 2013:24:195-209.

4. Papadopoulos NG, Arakawa $\mathrm{H}$, Carlsen $\mathrm{KH}$, et al. International consensus on (ICON) pediatric asthma. Allergy 2012:67:976-97.

5. Bousquet PJ, Burbach G, Heinzerling LM, et al. GA2LEN skin test study III: Minimum battery of test inhalent allergens needed in epidemiological studies in patients. Allergy 2009;64(11):1656-62.

6. Bousquet PJ, Chinn S, Janson C, et al. European community respiratory health survey I. Geographical variation in the prevalence of positive skin tests to environmental aeroallergens in the European community respiratory health survey I. Allergy 2007;62(3):301-9.

7. O'Connell EJ. The burden of atopy and asthma in children. Allergy 2004:59 (Suppl. 78):7-11.

8. Bousquet J, Bullinger M, Fayol C, et al. Assessment of quality of life in patients with perennial allergic rhinitis with the French version of the SF-36 health status questionnaire. J Allergy Clin Immunol 1994;94:182-8.

9. Williams $H$, Robertson $C$, Stewart $A$, et al. World wide variations in the prevalence of symptoms of atopic eczema in the international study of asthma and allergies in childhood. J Allergy Clin Immunol 1999;103:125-38.

10. Su JC, Kemp AS, Varigos CA, et al. Atopic eczema: Its impact on the family and financial cost. Arch Dis Child 1997;76:15962.

11. Başaran AE, Torun NK, Uygun DFK, et al. Akdeniz bölgesinde yaşayan atopik çocukların deri prick testlerindeki aeroalerjen dağılımları. Asthma Allergy Immunol 2018;16:132-7.

12. Arıkoğlu T, Batmaz SB, Kuyucu S. Allergic sensistization patterns in atopic children in Mersin Province of Turkey. Asthma Allergy Immunol 2018;16:1-6.

13. Elmas B, Özdemir Ö. Türkiye'nin Sakarya ilinde alerjik rinitli çocukların inhalan ve besin alerjenlerine duyarlılık prevalansı. JAREM 2017;7:63-9.

14. İğde $M$, Artıran İğde $F$, et al. Orta Karadeniz bölgesindeki çocuklarda allerji deri testi sonuçları. Turkiye Klinikleri J Pediatr 2009;18(2):82-90. 
15. Ayvaz A, Baki A, Gedik Y. Doğu Karadeniz bölgesindeki çocuklarda alerji deri testi (skin prick test) sonuçları. Turkiye Klinikleri J Allergy-Asthma 2003;5(2):80-4.

16. Işık S, Öğretmen Z, Kılıç $S$, et al. Çanakkale Onsekiz Mart Üniversitesi Tıp Fakültesi Dermatoloji Kliniği deri prik test sonuçları. J Clin Anal Med 2015;6(suppl 5):603-5.

17. Kuçukosmanoglu E, Tanıdır C, Demir F, et al. İstanbul'da çocuklarda solunum alerjenleri duyarlılığı. Gaziantep Tıp Dergisi 2009;15(3):10-3.

18. Sahiner UM, Civelek E, Yavuz ST, et al. Skin prick testing to aeroallergen extracts: What is the optimal panel in children and adolescents in Turkey? Int Arch Allergy Immunol 2012;157:391-8.

19. Paus Jenssen ES, Cockcroft DW. Sex differences in asthma, atopy and airway hyperresponsiveness in a university population. Ann Allergy Asthma Immunol 2003;91:34-7.

20. Durham SR, Kay AB. Eosinophils, bronchial hyperreactivity and late-phase asthmatic reactions. Clin Allergy 1985;15:4118.

21. Shields MD, Brown V, Stevenson EC, et al. Serum eosinophilic cationic protein and blood eosinophil counts for the pre- diction of the presence of airways inflammation in children with wheezing. Clin Exp Allergy 1999;29:1382-9.
22. Schleich FN, Chevremont A, Paulus V, et al. Importance of concomitant local and systemic eosinophilia in uncontrolled asthma. Eur Respir J 2014;44:97-108.

23. Zeiger R, Schatz M, Li Q, et al. High blood eosinophil count is a risk factor for future asthma exacerbations in adult persistent asthma. J Allergy Clin Immunol Pract 2014;2(6):741-50.

24. Bai $C$, Jiang $D$, Wang $L$, at al. A high blood eosinophil count may be a risk factor for incident asthma in population at risk. Respiratory Medicine 2019;(151):59-65.

25. Meteoroloji Genel Müdürlüğü (MGM): İklim sınıflandırmaları. Access date: 5 June 2019. Available from: http://mgm.gov.tr.

26. Kalpaklıoğlu AF, Emekçi M, Ferizli A, et al. House-Dust Mite Working Group. A survey of acarofauna in Turkey: Comparison of seven different geographic regions. Allergy Asthma Proc 2004;25:185-90.

27. Caraballo L, Zakzuk J, Lee BW, et al. Particularities of allergy in the tropics. World Allergy Organ J 2016;9:20.

28. Şaşihüseyinoğlu AŞ, Özhan AK, Serbes M, et al. Distribution of allergen sensitization in childhood by the use of skin test. Asthma Allergy Immunol 2017;15:43-8. 